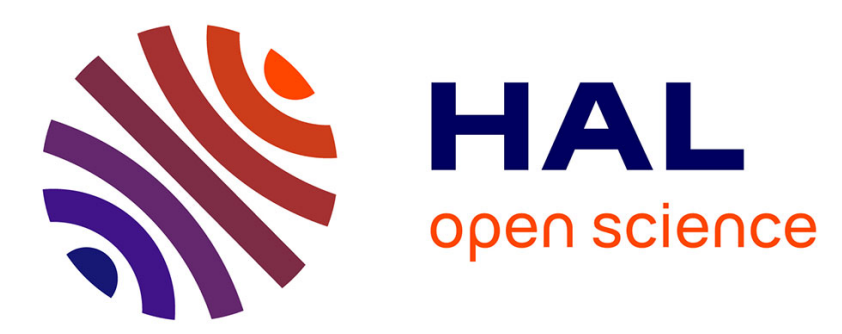

\title{
Enantioselective Synthesis of SSR 241586 by Using an Organo-Catalyzed Henry Reaction
}

\author{
Anne Cochi, Thomas-Xavier Metro, Domingo Gomez Pardo, Janine Cossy
}

\section{To cite this version:}

Anne Cochi, Thomas-Xavier Metro, Domingo Gomez Pardo, Janine Cossy. Enantioselective Synthesis of SSR 241586 by Using an Organo-Catalyzed Henry Reaction. Organic Letters, 2010, 12 (16), pp.3693 - 3695. 10.1021/ol101555g . hal-03228888

\section{HAL Id: hal-03228888 \\ https://hal.science/hal-03228888}

Submitted on 25 May 2021

HAL is a multi-disciplinary open access archive for the deposit and dissemination of scientific research documents, whether they are published or not. The documents may come from teaching and research institutions in France or abroad, or from public or private research centers.
L'archive ouverte pluridisciplinaire HAL, est destinée au dépôt et à la diffusion de documents scientifiques de niveau recherche, publiés ou non, émanant des établissements d'enseignement et de recherche français ou étrangers, des laboratoires publics ou privés. 


\title{
Enantioselective Synthesis of SSR 241586 by Using an Organo-Catalyzed Henry Reaction
}

\author{
Anne Cochi, Thomas-Xavier Métro, Domingo Gomez Pardo, and Janine Cossy ${ }^{\star}$ \\ Laboratoire de Chimie Organique, ESPCI ParisTech, CNRS, 10 rue Vauquelin, \\ 75231 Paris Cedex 05, France
}

janine.cossy@espci.fr
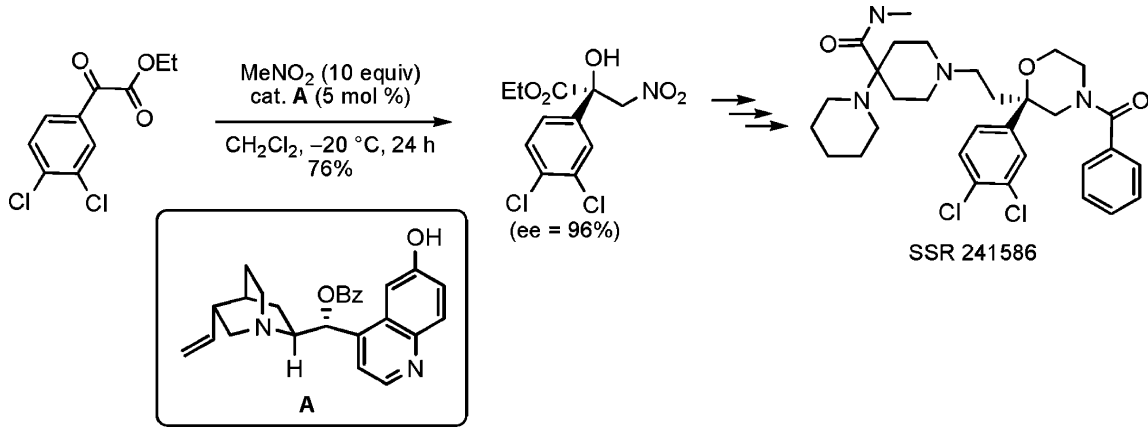

An organo-catalyzed Henry reaction, applied to an $\alpha$-keto ester, has allowed the enantioselective synthesis of SSR 241586, a 2,2-disubstituted morpholine active in the treatment of schizophrenia and irritable bowel syndrome (IBS).

Substance P (SP), neurokinin A (NKA), and neurokinin B (NKB) are the best known members of the tachykinin neuropeptide family which activity is mediated by at least three distinct receptors: NK1 (SP-preferring), NK2 (NKA-preferring), and NK3 (NKB-preferring). ${ }^{1}$ Due to their pharmacological effects on pain, on the central and peripheric system, as well as on the gastrointestinal and urogenital tracts, antagonists of NK receptors have attracted considerable attention as potentially powerful therapeutic agents. ${ }^{2}$ Among them, the optically active 2,2-disubstituted morpholines SSR 241586 and SSR 240600, developed by Sanofi-Aventis, were shown to be active in the treatment of depression, schizophrenia, urinary trouble, emesis, and irritable bowel syndrome (IBS) (Figure 1). ${ }^{3}$

So far, the methods reported to isolate the appropriate isomer of the 2,2-disubstituted morpholine include crystal-

(1) Pennefather, J. N.; Lecci, A.; Candenas, M. L.; Patak, E.; Pinto, F. M.; Maggi, C. A. Life Sci. 2004, 74, 1445-1463.

(2) (a) Rupniak, N. M. J.; Kramer, M. S. Trends Pharmacol. Sci. 1999, 20, 485-490. (b) Severini, C.; Improta, G.; Falconieri-Erspamer, G.; Salvadori, S.; Erspamer, V. Pharmacol. Rev. 2002, 54, 285-322. (c) Lecci, A.; Capriati, A.; Maggi, C. A. Br. J. Pharmacol. 2004, 141, 1249-1263.

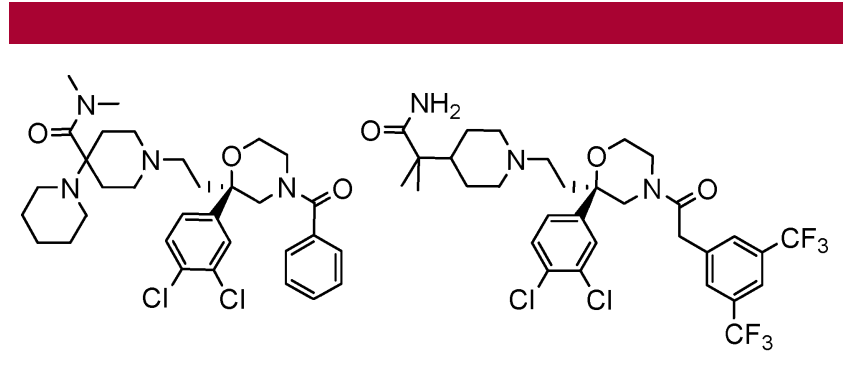

SSR 241586

Figure 1. SSR 241586 and SSR 240600.

lization with D-tartaric acid, ${ }^{4}$ Sharpless dihydroxylation (AD$\operatorname{mix} \beta),{ }^{5}$ asymmetric epoxydation of a homoallylic alcohol catalyzed by $\mathrm{Zr}(\mathrm{O}-\mathrm{t} \text {-Bu })_{4}$ and diisopropyl D-tartrate, ${ }^{6}$ as well as asymmetric cyanosilylation of a ketone using a Lewis acid/ Lewis base bifunctionnal catalyst. ${ }^{7}$

Here, we disclose an enantioselective synthesis of SSR 241586 using an organo-catalyzed Henry reaction to control the quaternary stereogenic center of $(R)$-configuration present at $\mathrm{C} 2$ in the 
morpholine ring. The synthesis of SSR 241586 was planed from the nucleophilic substitution of alcohol I with the appropriately substituted piperidine SSR 241579. Alcohol I would be obtained by homologation of ester II, and the construction of the morpholine ring would be achieved from the $\beta$-nitro alcohol III, which would be the result of an enantioselective Henry reaction applied to $\alpha$-keto ester IV (Scheme 1).

Scheme 1. Retrosynthesis of SSR 241586

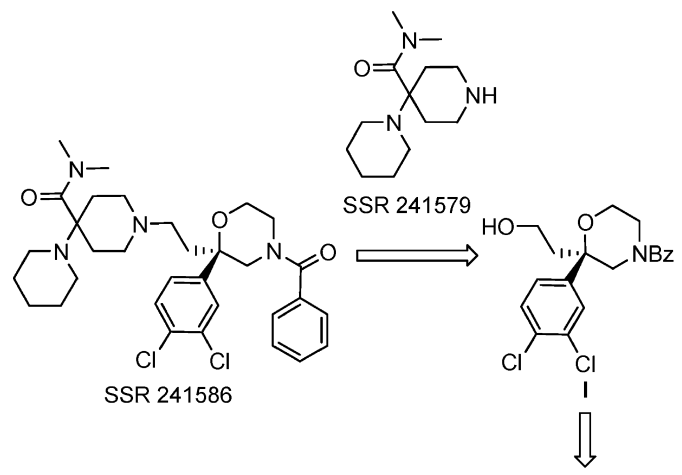

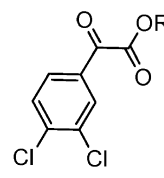

IV

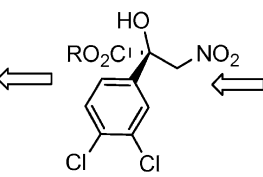

III

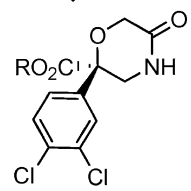

II
The synthesis of SSR 241586 started with the transformation of commercially available ethyl chlorooxoacetate (1) to ethyl $\alpha$-oxo- $1 H$-imidazole-1-acetate (2). ${ }^{8}$ When $\mathbf{2}$ was treated with 3,4-dichlorophenylmagnesium bromide, the desired $\alpha$-keto ester 3 was isolated in $74 \%$ yield. An organocatalyzed Henry reaction was subsequently applied to $\alpha$-keto ester 3. Quinine-derived compound $\mathbf{A}$ was chosen as the appropriate catalyst due to its ability to furnish Henry adducts with high enantiomeric excess on a broad range of substrates. ${ }^{9}$ Thus, treatment of $\mathbf{3}$ with nitromethane (10 equiv) in the presence of catalyst $\mathbf{A}(5 \mathrm{~mol} \%)$ in $\mathrm{CH}_{2} \mathrm{Cl}_{2}$ at $-20{ }^{\circ} \mathrm{C}$ produced $\beta$-nitro alcohol $\mathbf{4}^{10}$ in $76 \%$ yield and with an enantiomeric excess of $96 \%$ (Scheme 2).

The synthesis of the morpholine ring was achieved in four steps from nitro alcohol 4. At first, this latter was selectively reduced to

(3) (a) Emonds-Alt, X.; Proietto, V.; Steinberg, R.; Oury-Donzt, F.; Vigé, X.; Vilain, P.; Naline, E.; Daoui, S.; Advenier, C.; Le Fur, G.; Maffrand, J.-P.; Soubrié, P.; Pascal, M. J. Pharmacol. Exp. Ther. 2002, 303, 11711179. (b) Steinberg, R.; Alonso, R.; Rouquier, L.; Desvignes, C.; Michaud, J.-C.; Cudennec, A.; Jung, M.; Simiand, J.; Griebel, G.; Emonds-Alt, X.; Le Fur, G.; Soubrié, P. J. Pharmacol. Exp. Ther. 2002, 303, 1180-1188.

(4) Takemoto, T.; Iio, Y.; Nishi, T. Tetrahedron Lett. 2002, 41, 17851788 , and references cited therein.

(5) Nishi, T.; Ishibashi, K.; Nakajima, K.; Iio, Y.; Fukazawa, T. Tetrahedron: Asymmetry 1998, 9, 3251-3262.

(6) Okachi, T.; Murai, N.; Onaka, M. Org. Lett. 2003, 5, 85-87.

(7) Takamura, M.; Yabu, K.; Nishi, T.; Yanagisawa, H.; Kanai, M.; Shibasaki, M. Synlett 2003, 353-356.

(8) Nimitz, J. S.; Mosher, H. S. J. Org. Chem. 1981, 46, 211-213.

(9) Li, H.; Wang, B.; Deng, L. J. Am. Chem. Soc. 2006, 128, 732-733.

(10) The $(R)$ absolute configuration of the stereogenic center was determined by comparison of the $[\alpha]_{\mathrm{D}}$ to a previously described compound. See the Supporting Information for details. Nicewicz, D. A.; Yates, C. M.; Johnson, J. S. J. Org. Chem. 2004, 69, 6548-6555.
Scheme 2. Synthesis of the Optically Active Intermediate $(R)-\mathbf{4}$<smiles>CCOC(=O)C(=O)Cl</smiles>

1<smiles>CCOC(=O)C(=O)n1ccnc1</smiles>

2

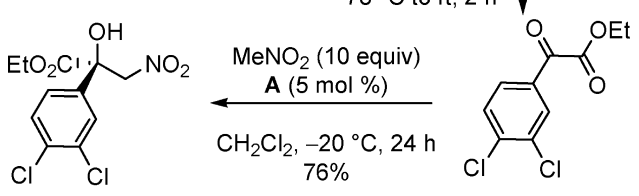

$(R)-4$ $(\mathrm{ee}=96 \%)$

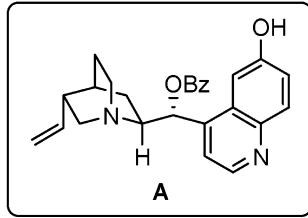

3

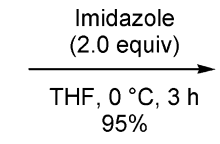

the corresponding amino alcohol $\mathbf{5}$. Under hydrogenation conditions, using Raney nickel $\left(\mathrm{H}_{2}\right.$, Raney $\left.\mathrm{Ni} / \mathrm{EtOH}\right)$, a retro-Henry reaction was observed. On the contrary, when the reduction of the nitro group was performed using zinc dust in acetic acid, the amino alcohol 5 was isolated without any racemization. $N$-Acetylation of the resulting primary amine $\left(\mathrm{ClCH}_{2} \mathrm{COCl}, \mathrm{Et}_{3} \mathrm{~N}, \mathrm{CH}_{2} \mathrm{Cl}_{2}, \mathrm{rt}, 4 \mathrm{~h}\right)$ produced amide $6(99 \%)$ which, after treatment with $\mathrm{NaH}$, afforded the cyclic amide 7 in $75 \%$ yield and with an enantiomeric excess of $96 \%$. The amide and ester groups were reduced by $\mathrm{BH}_{3} \cdot \mathrm{THF}$ ( 6 equiv, THF, reflux, $3 \mathrm{~h}$ ) to produce the 2,2-disubstituted morpholine 8 in $88 \%$ yield (Scheme 3 ).

In order to synthesize SSR 241586, compound 8 has to be transformed to its homologue 11. Thus, 8 was treated with di-tert-butyl dicarbonate $\left(\mathrm{Boc}_{2} \mathrm{O}, \mathrm{Et}_{3} \mathrm{~N}, \mathrm{MeOH}, \mathrm{rt}, 16 \mathrm{~h}\right)$ to produce the $N$-protected morpholine 9 (93\% yield). An oxidation step [Dess-Martin periodinane (DMP), $\mathrm{CH}_{2} \mathrm{Cl}_{2}$, $\mathrm{rt}, 1 \mathrm{~h}$ ] followed by a Wittig reaction (KHMDS, $\mathrm{BrPPh}_{3} \mathrm{CH}_{3}$, THF) provided olefin $\mathbf{1 0}$ ( $82 \%$ for the two steps), and after an oxidative hydroboration $\left(\mathrm{BH}_{3} \cdot \mathrm{Me}_{2} \mathrm{~S}\right.$, then $\left.\mathrm{H}_{2} \mathrm{O}_{2}, \mathrm{NaOH}\right)$, alcohol 11 was isolated in $64 \%$ yield. In order to introduce the $N$-benzoyl group present in the final product, a deprotection/protection step was achieved.

Thus, $N$-tert-butyl carbamate $\mathbf{1 1}$ was treated with TFA $\left(\mathrm{CH}_{2} \mathrm{Cl}_{2}\right.$, $\mathrm{rt}, 1 \mathrm{~h}$ ), and the resulting morpholine was then transformed into the $\mathrm{N}$-benzoylmorpholine $\mathbf{1 3}\left(\mathrm{PhCOCl}, \mathrm{Et}_{3} \mathrm{~N}, \mathrm{CH}_{2} \mathrm{Cl}_{2}, \mathrm{rt}, 1.25 \mathrm{~h}\right.$ ) in $45 \%$ yield (for the two steps) (Scheme 4 ).

We have to point out that the straightforward access to SSR 241586 from $\mathbf{8}$, by transforming the latter in $N$-benzoylmorpholine, was not possible. Indeed, after transformation of $\mathbf{8}$ to $N$-benzoylmorpholine $\mathbf{9}^{\prime}$, this compound was converted to olefin $\mathbf{1 0}^{\prime}$ in two steps (DMP, $\mathrm{CH}_{2} \mathrm{Cl}_{2} ; \mathrm{BrPPH}_{3} \mathrm{CH}_{3}, t$-BuOK, THF), but unfortunately, the oxidative hydroboration of $\mathbf{1 0}^{\prime}$ was not successful as $\mathbf{1 3}$ was not formed (Scheme 5).

The formation of SSR 241586 was completed from $\mathbf{1 3}$ in two steps. After mesylation ( $\mathrm{MsCl}, \mathrm{Et}_{3} \mathrm{~N}, \mathrm{CH}_{2} \mathrm{Cl}_{2}, \mathrm{rt}, 1 \mathrm{~h}$ ) and treatment of the resulting mesylate with piperidine SSR 
Scheme 3. Synthesis of the 2,2-Disubstituted Morpholine 8<smiles>CCOC(=O)[C@H](O)c1ccc(Cl)c(Cl)c1</smiles><smiles>CCOC(=O)c1ccc(Cl)c(Cl)c1</smiles>
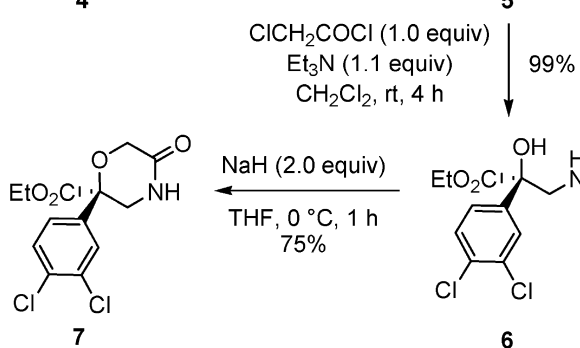

$(e e=96 \%)$<smiles>CCOC(O)(CNC(=O)CCl)c1ccc(Cl)c(Cl)c1</smiles>

6
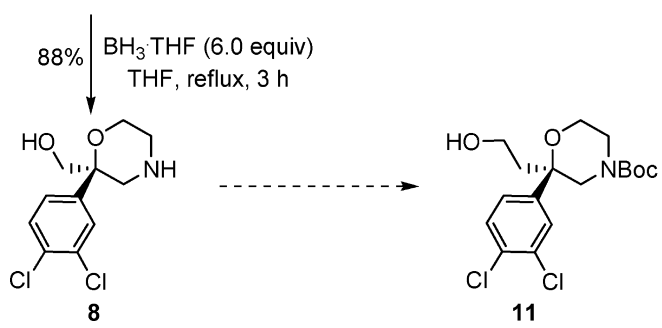

Scheme 4. Homologation of the Side Chain
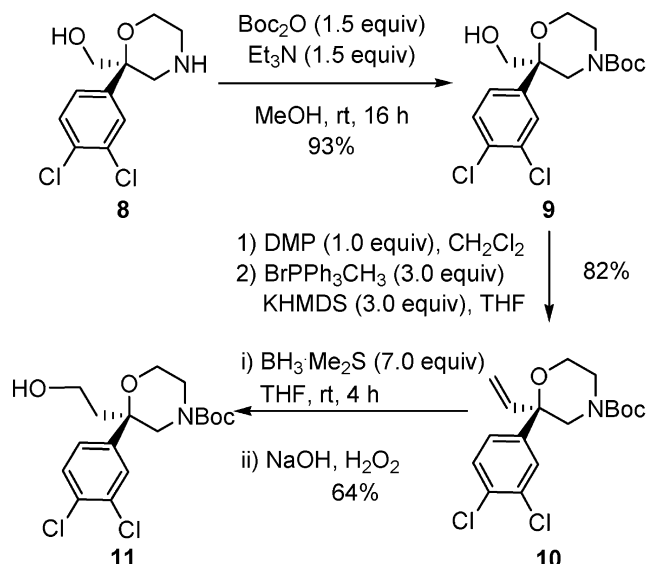

$$
67 \%\left\lfloor\begin{array}{c}
\mathrm{TFA}, \mathrm{CH}_{2} \mathrm{Cl}_{2} \\
\mathrm{rt}, 1 \mathrm{~h}
\end{array}\right.
$$

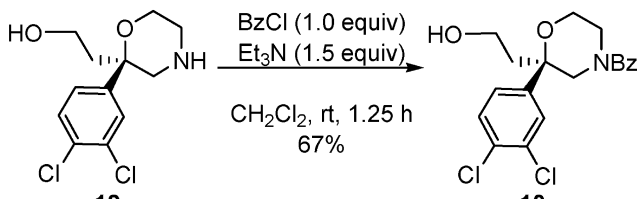

13

241579 [N,N-dimethyl-4-(piperidin-1-yl)piperidine-4-carboxamide $]^{11}$ under basic conditions $\left(\mathrm{K}_{2} \mathrm{CO}_{3}, \mathrm{DMF} / \mathrm{CH}_{3} \mathrm{CN}\right.$ $1: 1,100{ }^{\circ} \mathrm{C}, 3 \mathrm{~h}$ ), the desired SSR 241586 was isolated in $48 \%$ yield (two steps) with an enantiomeric excess of $93 \%$ (Scheme 6). ${ }^{12}$
Scheme 5. Homologation of the Side Chain with $N$-Benzoylmorpholine $\mathbf{9}^{\prime}$
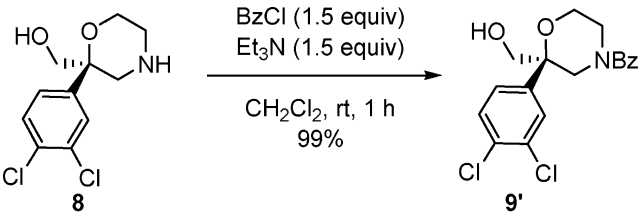

$$
\text { (ee }=94 \%)
$$

1) $\mathrm{DMP}$ (1.0 equiv), $\mathrm{CH}_{2} \mathrm{Cl}_{2}$

2) $\mathrm{BrPPh}_{3} \mathrm{CH}_{3}$ (1.5 equiv) tBuOK ( 1.5 equiv), THF

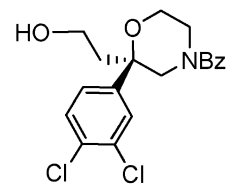

13

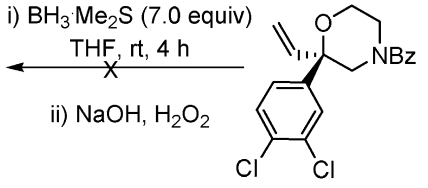

$10^{\prime}$
Scheme 6. Synthesis of SSR 241586

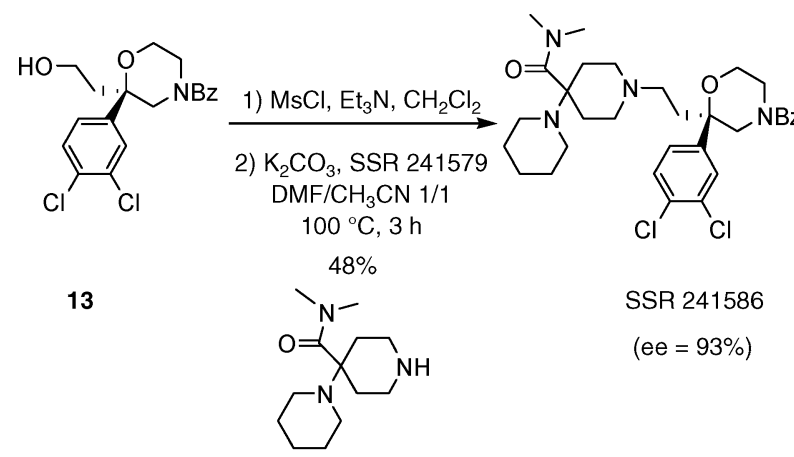

SSR 241579

By using an organo-catalyzed Henry reaction, SSR 241586 was synthesized in 15 steps with an excellent enantiomeric excess. As this method is versatile, a number of optically active 2,2-disubstituted morpholine analogues of SSR 241586 could be obtained.

Acknowledgment. Sanofi-Aventis is greatly acknowledged for financial support (T.-X.M.). We also thank Dr. Vincent Ferrey and Sylvie Vigne (Sanofi-Aventis) for furnishing a sample of SSR 241579.

Supporting Information Available: Experimental procedure and characterization data of compounds 2-13 and SSR 241586. This material is available free of charge via the Internet at http://pubs.acs.org.

\section{OL101555G}

(11) (a) Edmonds-Alt, X.; Proietto, V. F.R. Patent 2824828, 2002; Chem. Abstr. 2002, 137, 384848. (b) SSR 241579 was provided by SanofiAventis.

(12) Edmonds-Alt, X.; Grossriether, I.; Gueule, P.; Proietto, V.; Van Broeck, D. W.O. Patent 9623787, 1996; Chem. Abstr. 1996, 125, 247839. 